\title{
Expression pattern of heat shock proteins during acute thermal stress in the Antarctic sea urchin, Sterechinus neumayeri
}

\author{
Karina González ${ }^{1}$, Juan Gaitán-Espitia ${ }^{2,3}$, Alejandro Font ${ }^{1}$, César A. Cárdenas ${ }^{1}$ and Marcelo González-Aravena ${ }^{*}$
}

\begin{abstract}
Background: Antarctic marine organisms have evolved a variety of physiological, life-history and molecular adaptations that allow them to cope with the extreme conditions in one of the coldest and most temperaturestable marine environments on Earth. The increase in temperature of the Southern Ocean, product of climate change, represents a great challenge for the survival of these organisms. It has been documented that some Antarctic marine invertebrates are not capable of generating a thermal stress response by means of an increase in the synthesis of heat shock proteins, which could be related with their low capacity for acclimatization. In order to understand the role of heat shock proteins as a compensatory response in Antarctic marine species to projected scenarios of increased seawater temperatures, we assessed the expression of the genes Hsp90, Grp78, Hyou1 and $\mathrm{Hsc} 70$ in the Antarctic sea urchin Sterechinus neumayeri under three thermal treatments $\left(1^{\circ} \mathrm{C}, 3^{\circ} \mathrm{C}\right.$ and $\left.5^{\circ} \mathrm{C}\right)$, for a period of exposure of 1, 24 and $48 \mathrm{~h}$.

Results: The results obtained showed that these genes were expressed themselves in all of the tissues analyzed in a constitutive form. During acute thermal stress, an overexpression of the Hsp90, Grp78 and Hyou1 genes was observed in coelomocyte samples at $3{ }^{\circ} \mathrm{C}$ after $48 \mathrm{~h}$, while in esophageal samples, an increase in Hsp90 and Grp78 expression was observed after $48 \mathrm{~h}$. Thermal stress at $5^{\circ} \mathrm{C}$, in general, did not produce a significant increase in the expression of the genes that were studied. The expression of Hsp70 did not show modifications in its expression as a result of thermal stress.

Conclusions: S. neumayeri is capable of overexpressing stress proteins as a result of thermal stress, however, this response is delayed and to a lesser degree compared to other Antarctic or temperate species. These results indicate that adult individuals could cope with the expected impacts caused by an increase in coastal sea temperatures in the Southern Ocean.
\end{abstract}

Keywords: HSP, Thermal tolerance, Chaperones, Ocean warming, Sea urchin

\section{Background}

During the last 35 million years, Antarctic marine organisms have evolved a variety of physiological, lifehistory and molecular adaptations that allow them to cope with the extreme conditions in one of the coldest and most temperature-stable marine environments on Earth $[1,2]$. Some of the most notable adaptations in these highly stenothermal species are the production of antifreeze peptides in notothenioid fishes [3], the higher

\footnotetext{
*Correspondence: mgonzalez@inach.cl

'Laboratorio de Biorecursos Antárticos, Departamento Científico. Instituto

Antártico Chileno, Punta Arenas, Chile

Full list of author information is available at the end of the article
}

accumulation of polyunsaturated fatty acyl chains in microorganisms [4], the slow growth rates, low basal metabolism and reduced annual reproductive effort in ectothermic invertebrates [5], as well as other specific cellular or metabolic processes in marine invertebrates [6]. Even though the evolution of these adaptations has permitted life in an extreme environment, it has also reduced the capacity of the majority of Antarctic species to adapt to new environmental conditions $[7,8]$. In fact, an important constraint in thermal niche expansion for Antarctic species is the loss of traits whose function is to increase heat tolerance or to facilitate acclimatization to short-term changes in temperature $[9,10]$. This 
functional limitation is suggested to be the result of the absence of positive selection during evolution at stable sub-zero temperatures [10].

From a physiological perspective, chronic exposure to extreme temperatures (e.g. cold or heat) is expected to cause thermal stress and deleterious effects on organismal performance [11]. However, organisms can compensate variations of environmental temperatures by modification of their molecular and cellular structures to maintain performance as their environments change [12, 13]. One of the main molecular responses that is activated in a cell under thermal stress is the production of heat shock proteins (HSP), being the Hsp70 family the most studied in its constitutive (Hsc70) and inducible (Hsp70) forms [14]. As molecular chaperones, HSPs stabilize denaturing proteins and refold those that have already been denatured $[15,16]$, thus, the HSP responsecould be considered an ecologically and evolutionarily important factor in thermal adaptation, setting thermal tolerance limits and improving an animal's tolerance to thermal stress [16-18]. Nevertheless, physiological responses to thermal stress conditions are not uniform among different taxa. For instance, it has been documented that some species of marine organisms are capable of generating a thermal stress response, while others have lost such capacity or simply do not have the necessary physiological mechanisms to generate this response [19]. To date, empirical evidences on a very limited number of genes have shown that the mollucs Nacella concinna and Laternula elliptica are the only Antarctic marine species with a protein induction response to thermal stress $[20,21]$, whereas other species such as the Antarctic notothenioids fish, the seastar Odontaster validus and the gammarid crustacean Paraceradocus gibber, cannot respond with an increase of gene expression after chronic thermal exposure $[19,22$, 23]. Understanding the role of physiological plasticity as a compensatory response in Antarctic marine species to projected scenarios of increased seawater temperatures is one of the main challenges in order to predict their capacity to adapt to climate change [24].

In the Antarctic Peninsula, long-term environmental monitoring programs have revealed a rapid increase in mean and extreme temperatures, with an elevation of the surface temperature of the Bellingshausen Sea by $1{ }^{\circ}$ $C$ in the past 50 years $[25,26]$. Although there have been pronounced seasonal changes in the surface temperature of the Antarctic ocean, the data obtained during five years (2006-2010) of the surface temperatures in Arthur Harbor (Anvers Island, Antarctica), showed extreme events of maximum temperatures $\left(2.9{ }^{\circ} \mathrm{C}\right)$ during the austral summer in February 2009 [27]. These changes in sea surface temperature (increases of $2-3{ }^{\circ} \mathrm{C}$ ) represent a great challenge for Antarctic marine species as these may decrease their essential biological functions [28, 29]. Although Antarctic organisms can functionally operate for short-term in temperature ranges between 5 and $12^{\circ}$ $\mathrm{C}$ above the minimum sea temperature of $-2{ }^{\circ} \mathrm{C}$ [30], most of them are unable to survive for long-term the increase of $2-3{ }^{\circ} \mathrm{C}$ [8]. The more tolerant species have shown maintenance of physiological performance for a few months in temperatures surrounding $6{ }^{\circ} \mathrm{C}$ [31], which are close to the projected temperatures for 2100 in this region [32].

To explore the physiological capacity of Antarctic organisms to physiologically compensate drastic thermal events such as those predicted to occur in surface oceans at the end of the century; we assessed the HSP response in the Antarctic sea urchin Sterechinus neumayeri. Thanks to the advances of Next-Generation Sequencing technologies (NGS), we are now able to search for target genes related to heat stress chaperones from the whole transcriptome of this species [33]. These chaperones proteins have been classified into several families based on their molecular mass and functions. The Hsp90 have key roles in the maturation of signal transduction proteins, like hormone receptors and protein folding [34]. Hsp70 proteins are necessary for protein folding, multimer dissociation and association, translocation of proteins across membranes, and regulation of the heat shock response [35]. The Glucoseregulated protein 78 (Grp78) or HspA5 is required for endoplasmic reticulum integrity and stress-induced autophagy [36]. The Hypoxia up-regulated 1 (Hyou 1 or Grp170) under hypoxia condition is accumulated in the endoplasmic reticulum (ER) and this gene play an important role in protein folding, secretion in the ER and an important cytoprotective role during the hypoxia [37]. In this work, we determined the capacity of adult $S$. neumayeri to induce transcriptional activity for the production of the Hsp90 (heat shock protein $90 \mathrm{kDa}$ ), Hsc70 (heat shock cognate $70 \mathrm{kDa}$ ), Grp78 (glucose-regulated protein $78 \mathrm{kDa}$ ) and Hyoul (hypoxia upregulated 1) genes in the coelomocyte and esophagus after exposure to acute thermal stress over a short-term stress period.

\section{Methods}

\section{Animal sampling and experimental set-up}

Antarctic sea urchins were collected by SCUBA divers during the austral summer at Maxwell Bay $\left(62^{\circ} 12^{\prime} 12.2^{\prime \prime}\right.$ S - 58 $56^{\prime} 41.7^{\prime \prime}$ W), Fildes Peninsula, King George Island. Subsequently animals were kept in a cold chamber with re-circulating seawater at room temperature $(1.0 \pm$ $1.0^{\circ} \mathrm{C}, 34 \%$ salinity) and constant aeration. Specimens were acclimated for one week before experiments. Thirty-two individuals of $S$. neumayeri were randomly selected and maintained in the three experimental 
treatments $\left(1{ }^{\circ} \mathrm{C}, 3{ }^{\circ} \mathrm{C}\right.$ and $\left.5{ }^{\circ} \mathrm{C}\right)$ for $48 \mathrm{~h}$. Animals were directly transferred from control temperature $\left(1{ }^{\circ} \mathrm{C} \pm\right.$ $0.5^{\circ} \mathrm{C}$ ) to the experimental aquariums for acute thermal stress without an acclimation period at $3{ }^{\circ} \mathrm{C}$ and $5{ }^{\circ} \mathrm{C}$. Eight animals were assigned to the control group and 12 to each of the thermal stress treatments. Four sea urchins were randomly collected from each group at 1,24 and $24 \mathrm{~h}$ post thermal stress, respectively. Coelomocyte and tissue samples were obtained and stored in RNA later according to manufacturer instructions (Ambion).

\section{Mining target genes}

The nucleotide sequences of the genes coding for Hsp90, Hsc70, and Grp78 Hyou1 chaperones were obtained from the transcriptome of $S$. neumayeri larvae (Bioproject ID N ${ }^{\circ}$ PRJNA252503), which was generated by the 454 technology [33]. The degree of homology of these sequences was confirmed by similarity search using Blastx program NCBI (Table 1), where amino acid sequences were extracted for a multiple alignment using the Clustal program to determine conserved areas. Subsequently, from the conserved areas the primers were designed using the software Primer 3.0.

\section{RNA extraction and synthesis of CDNA}

Total RNA was extracted from S. neumayeri from coelomocytes, digestive tracts, esophagus and gonads using an E.Z.N.A. Total RNA Kit and treated after with DNAse according to the manufacturer's instructions. The quantity and the integrity of the total RNA was then assessed by spectrophotometric and agarose gel electrophoresis, respectively. Synthesis of the cDNA from approximately $1 \mu \mathrm{g}$ of the total RNA was carried out using Random Hexamers 50uM (Roche), $1 \mathrm{mM}$ dNTPs (Invitrogen), $20 \mathrm{U}$ RnaseOUT (Invitrogen) and $50 \mathrm{U}$ M-MLV reverse transcriptase in reverse transcriptase buffer (Invitrogen) according to the manufacturers' instructions in a final volume of $20 \mu \mathrm{l}$. The cDNA was then diluted ten times and $2 \mu \mathrm{l}$ were used for PCR reactions. The cDNA was amplified by PCR, using $1 \mathrm{U}$ of Taq polymerase (Invitrogen) and $1 \mu \mathrm{M}$ of each primer (see Table 2), at a final volume of $25 \mu$ l. An amplification program for PCR consisted in $5 \mathrm{~min}$ at $94{ }^{\circ} \mathrm{C}$, followed by 30 cycles of $94{ }^{\circ} \mathrm{C}$ for $45 \mathrm{~s}, 55{ }^{\circ} \mathrm{C}$ for $45 \mathrm{~s}$, and $72{ }^{\circ} \mathrm{C}$ for $1 \mathrm{~min}$, and finally an elongation step at $72{ }^{\circ} \mathrm{C}$ for $10 \mathrm{~min}$.
Amplified products were analyzed on $1 \%$ agarose gels and sequenced from both directions using the same set of primers.

\section{mRNA expression analysis by real time PCR}

Quantitative PCR analysis was carried out to determine whether there were acute changes in gene expression, sampled at 1,24 and $48 \mathrm{~h}$ during the acute thermal stress. These qPCR reactions were composed by $2.0 \mu \mathrm{l}$ of cDNA diluted at 1:10 ratio, $0.5 \mu \mathrm{l}$ of both primers $(5 \mu \mathrm{M})$ adding $7 \mu \mathrm{l}$ of a ready to use solution of Brilliant II Sybr Green qPCR Master (Stratagene) into a final volume of $20 \mu \mathrm{l}$ complete with water. Amplification conditions, were performed in Agilent Mx3005P Thermocycler, consisted in 40 cycles, $95{ }^{\circ} \mathrm{C}$ for $10 \mathrm{~min}$; $95^{\circ} \mathrm{C}$ for $15 \mathrm{~s} ; 52^{\circ} \mathrm{C}$ for $\mathrm{s} ; 72{ }^{\circ} \mathrm{C}$ for $15 \mathrm{~s}$ with a single fluorescence measurement; melting curve program and finally a cooling step. Primer pair efficiencies (E) were calculated from six serial dilutions of pooled cDNA for each primer pair. Primer pair efficiencies were calculated from the given slopes in the software MxProTM (Agilent Technologies) software according to the equation: $\mathrm{E}=$ $10[-1 /$ slope $]$. Specificity of a qPCR product was determined by agarose gel electrophoresis and melting curve analysis.

For further analysis of the expression level, the crossing points $(\mathrm{CP})$ were determined for each transcript, using the MxProTM software QPCR System (Agilent Technologies). Four separate individuals were used for each gene tested in real time quantitative PCR reactions. The copy ratio of each analyzed cDNA was determined as the mean of two technical replicates. The relative expression level of chaperone genes was calculated based on the 2- $\triangle \Delta \mathrm{CP}$ method using the average of GAPDH/ $18 \mathrm{~S}$ as the reference gene [38]. Calculations of means, standard deviations and statistical analysis using the Kruskal-Wallis test for expression analysis were carried out using GraphPad Prism software version 5.0. A value of $p<0.05$ indicated statistical significant difference.

\section{Results}

The primers, designed to amplify the selected sequences, specifically amplified PCR products between 150 and 218 base pairs. The efficiency of the primers used had

Table 1 Identity between amino acid sequences of heat shock proteins obtained from Sterechinus neumayeri and Strongylocentrotus purpuratus

\begin{tabular}{llllll}
\hline Gen & Closest database match & Score & \% Identity & Probability (e-value) & Genbank accesión number \\
\hline Hsp90 & Strongylocentrotus purpuratus & 1221 & 94 & 0.0 & XP_003725294.1 \\
Hsc70 & Strongylocentrotus purpuratus & 1130 & 89 & 0.0 & XP_802129.1 \\
Hyou1 & Strongylocentrotus purpuratus & 634 & 78 & 0.0 & XP_011661677.1 \\
Grp78 & Strongylocentrotus purpuratus & 977 & 91 & 0.0 & XP_003728714.1 \\
\hline
\end{tabular}


Table 2 Primers used for $\mathrm{qPCR}$

\begin{tabular}{|c|c|c|c|c|c|c|}
\hline Gene target & GenBank accession & Direction & Primer DNA sequence & Size of the amplicon (pb) & RSq & PCR Efficiency (\%) \\
\hline \multirow[t]{2}{*}{ Hsp90 } & isotig08469 & FW & CCGATGCTTTGGACAAGATTC & 151 & 0.989 & 122.4 \\
\hline & & Rv & ATGTCAGCCTTGGTCATTCC & & & \\
\hline \multirow[t]{2}{*}{$\mathrm{Hsc} 70$} & isotig04537 & FW & ACAAGAGGGCAGTCAGGAGA & 218 & 0.982 & 121.6 \\
\hline & & Rv & TITGCCCAACTTGGAGTCAC & & & \\
\hline \multirow[t]{2}{*}{ Hyou1 } & isotig05161 & FW & ATGACATGGGTGCTGGTAGT & 170 & 0.992 & 123.4 \\
\hline & & Rv & TGCAAGGTGCTTCTGAAGAC & & & \\
\hline \multirow[t]{2}{*}{ Grp78 } & isotig04367 & FW & CGACTTGGGCACAACCTATT & 203 & 0.980 & 116.5 \\
\hline & & Rv & TTCCGATCAACCTCTTGGCAT & & & \\
\hline \multirow[t]{2}{*}{ Gapdh } & & FW & AAGGAGGAGCCAAGAAGGTC & 93 & 0.999 & 109.5 \\
\hline & & Rv & TCCCTGCATCGTATTCCTTC & & & \\
\hline \multirow[t]{2}{*}{$18 \mathrm{~S}$} & & FW & GAGCCTGCGCTTAATTTGAC & 186 & 0.998 & 109.2 \\
\hline & & Rv & GGCGCAACTATTTAGCAAGC & & & \\
\hline
\end{tabular}

values over $100 \%$ and acceptable for qPCR applications (Table 2).

Transcriptomic profiles of adult animals under control conditions $\left(1{ }^{\circ} \mathrm{C}\right)$, showed signals of expression of the Hsp90, Hsc70, Grp78 and Hyou1 genes in the different tissues (coelomocytes, gonads, esophagus and digestive tract). The overall response of Hyou1 and Grp78 genes showed a lower level of expression in coelomocytes in comparison to other tissues in a control condition (Fig. 1). Nevertheless, significant differences were not found in the expression of HSP genes among the four tissues $(p>0.05)$.
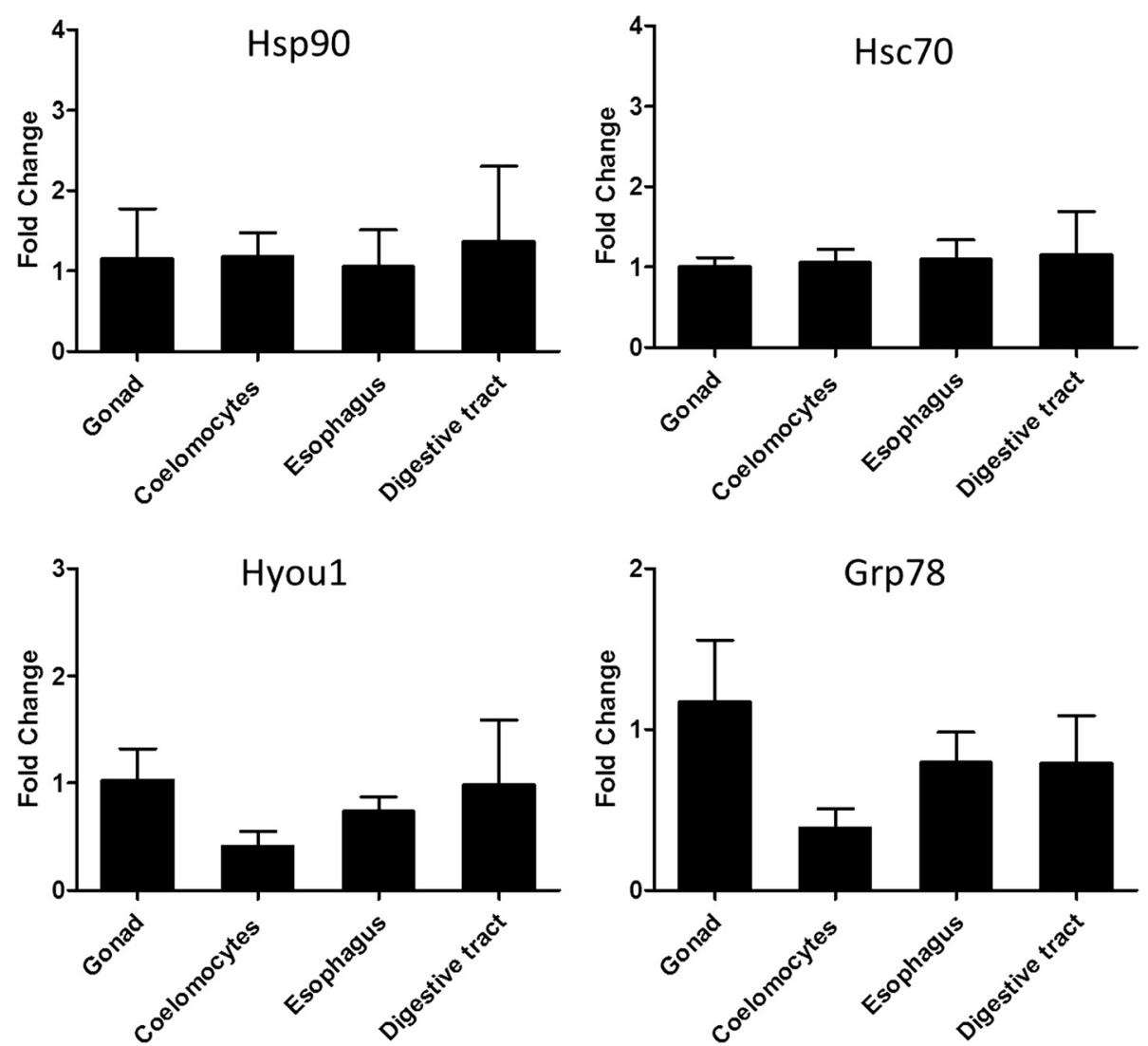

Fig. 1 Tissues expression of chaperones mRNA under control condition. The genes were measured in four different tissues. Endogenous control genes for quantification was the mean of Gapdh and18s. The relative mRNA expression of each tissue was compared to gonad expression to determine the tissue specific expression. No significant differences were found between treatments $(p>0.05)$ 
On the other hand, the analysis of the level of expression of the Hsp90 gene showed a significant increase in coelomocytes at $3{ }^{\circ} \mathrm{C}$ only after $48 \mathrm{~h}(p<0.05)$ (Fig. 2). Interestingly, at the higher experimental temperature $\left(5{ }^{\circ} \mathrm{C}\right)$, the expression of this gene was not significantly different when compared to the control conditions or the lower thermal stress treatment. Similarly to the coelomocytes profile, the expression of the Hsp90 in the esophagus showed significantly differences at $3{ }^{\circ} \mathrm{C}$ after $48 \mathrm{~h}$, while at the $5{ }^{\circ} \mathrm{C}$ treatment, a significant increase was observed only after the first hour (Fig. 3).

The expression during thermal stress in three members of the Hsp70 gene family was analyzed in coelomocytes and esophagus. The expression of Hsc70 did not show a significant increase for any temperature and time evaluated in both tissues. The expression of the Hsc70 in the tissues sampled tended to have a lower expression compared to the control condition, however it was not significant. In contrast, the expression of gene Hyou1 and Grp78 showed a significant increase $(p<0.05)$ in coelomocytes at $48 \mathrm{~h}$ at $3{ }^{\circ} \mathrm{C}$ (Fig. 2). During thermal stress at $5{ }^{\circ} \mathrm{C}$, the expression of both genes was not increased compared to the control condition. In the esophagus, both genes presented a different expression profile. Hyou 1 showed an increase at 1 and 24 h, however it was not significant. On the other hand, the gene
Grp78 showed a similar profile to that observed in coelomocytes, being significant at $48 \mathrm{~h}$ at $3{ }^{\circ} \mathrm{C}$ (Fig. 3). Thermal stress at $5{ }^{\circ} \mathrm{C}$, in the esophagus, did not generate an increase in the expression of these two genes.

\section{Discussion}

This investigation is the first description of the expression of chaperones proteins in different tissues of the Antarctic sea urchin S. neumayeri during acute thermal stress. To date, few investigations in Antarctic marine invertebrates have evaluated the thermal stress response associated with the expression of different chaperones in different tissues [19]. In Antarctic echinoderms the expression of chaperones type Hsp70 has been assessed only in of the starfish O.validus has been evaluated [22]. Therefore, generating new information and molecular resources in other echinoderms species is mandatory in order to understand how these highly vulnerable Antarctic marine invertebrates have faced the current and futures changes in sea water temperature in the Antarctic Peninsula as well as to predict the ecophysiological implications under future climate change scenarios [39]. Although, experimental temperatures used in this investigation matched some of those used with previous studies [19], these temperatures do not correspond to the current environmental temperatures found in the
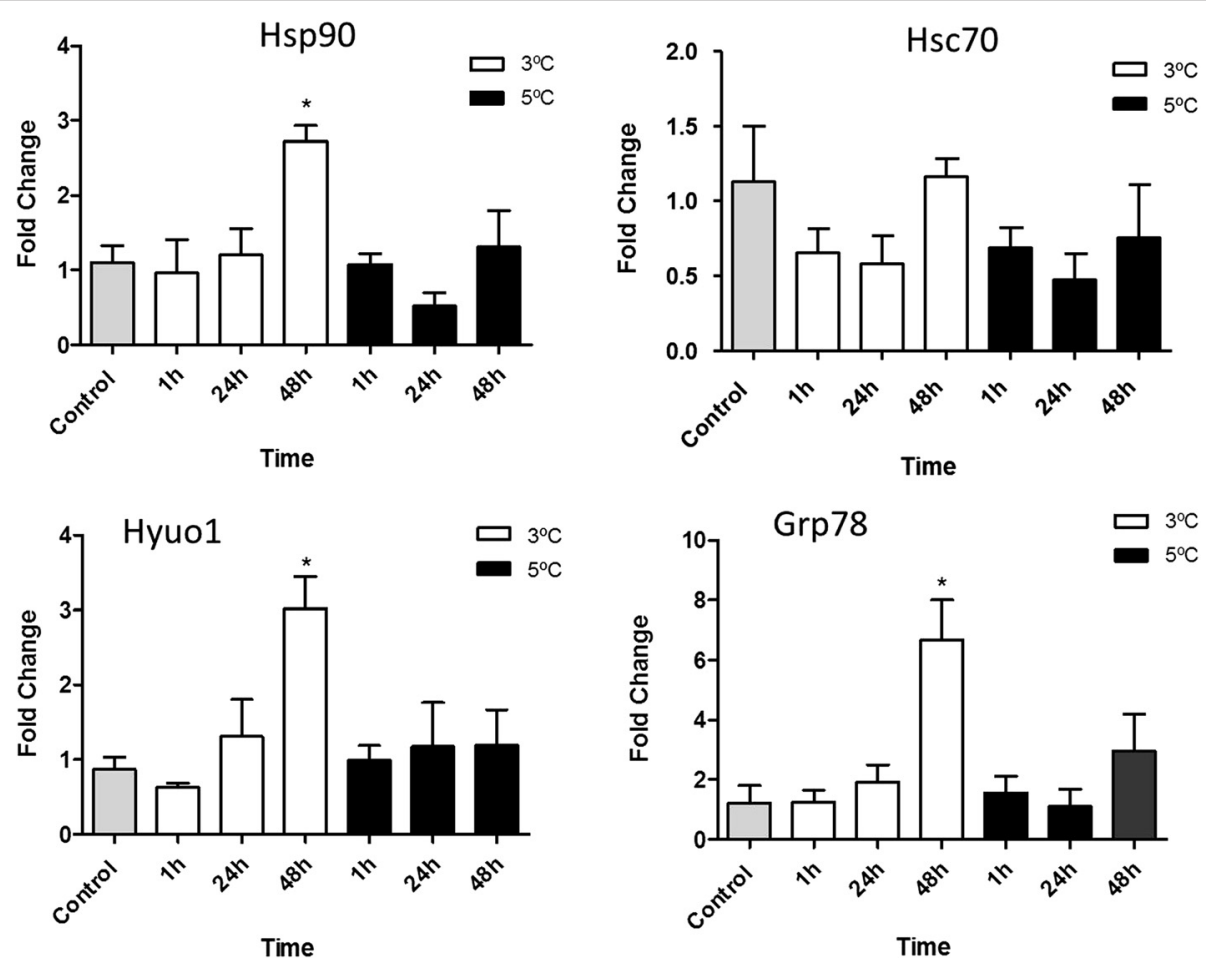

Fig. 2 Variation of gene expression during acute thermal stress in coelomocytes of S. neumayeri. Antarctic sea urchins were exposed to $3{ }^{\circ} \mathrm{C}$ and $5{ }^{\circ} \mathrm{C}$ for 1,24 and $48 \mathrm{~h}$. Grey bars: control group; white bars: $3^{\circ} \mathrm{C}$ and black bars: $5^{\circ} \mathrm{C}$. Bars represent the mean of four individuals and error bars are standard error. ${ }^{*} p<0.05$ 

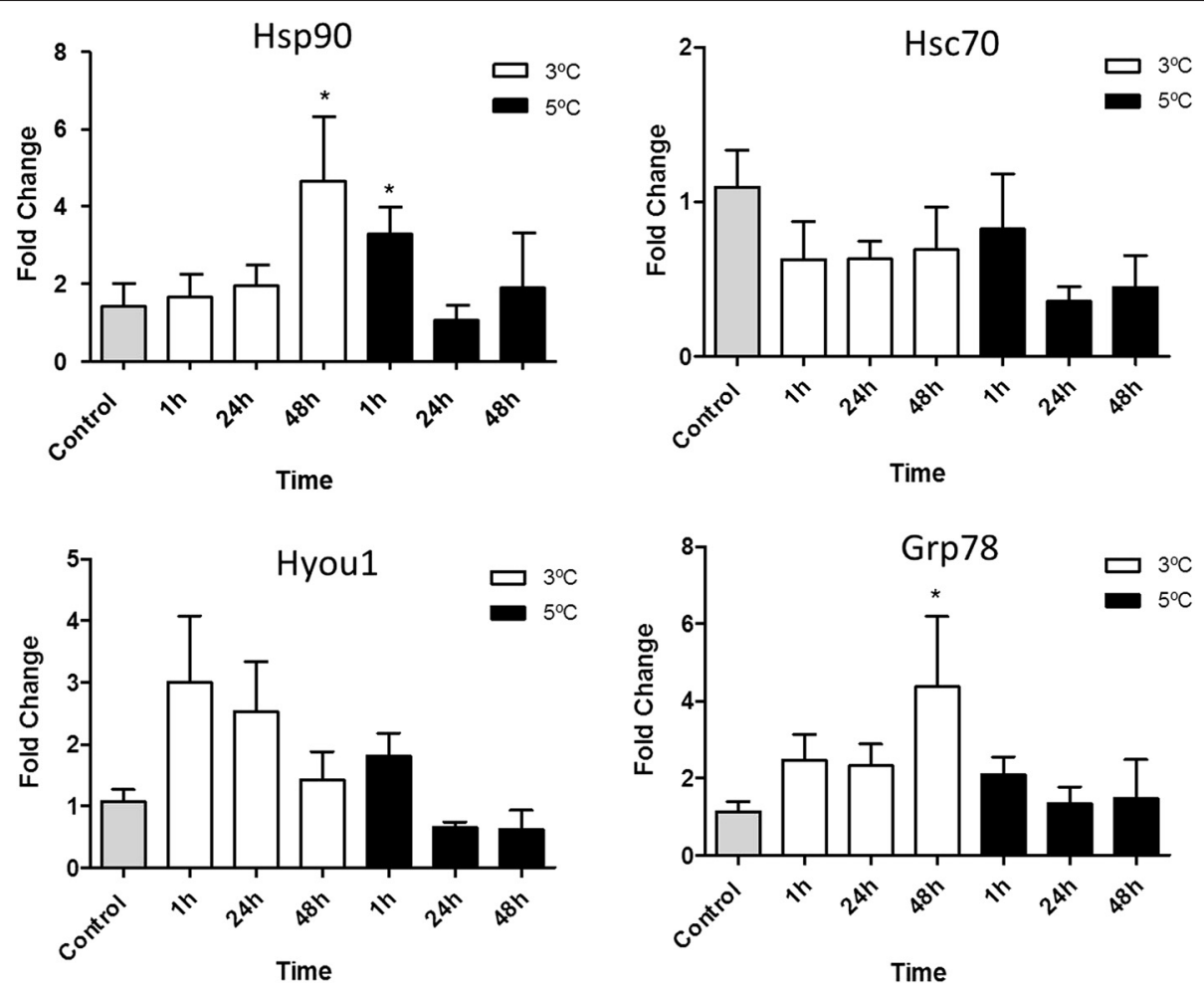

Fig. 3 Variation of gene expression during acute thermal stress in esophagus tissue of S. neumayeri. Antarctic sea urchins were exposed to $3^{\circ} \mathrm{C}$ and $5{ }^{\circ} \mathrm{C}$ for 1, 24 and $48 \mathrm{~h}$. Grey bars: control group; white bars: $3^{\circ} \mathrm{C}$ and black bars: $5{ }^{\circ} \mathrm{C}$. Bars represent the mean fold of four individuals and error bars are standard error. ${ }^{*} p<0.05$

Antarctica. However, it is already possible to find temperatures close to $3{ }^{\circ} \mathrm{C}$ in some areas of the Antarctic Peninsula [27], therefore, the information obtained by us at $3{ }^{\circ} \mathrm{C}$ is ecologically relevant and may indicate the real capacity of these species to respond to extreme thermal events in their natural environments.

The analysis of the expression of the Hsp90, Hsc70, Hyou1 and Grp78 genes of S.neumayeri during thermal stress, showed that these genes expressed themselves in a constitutive form in the four tissues evaluated. Since low temperatures can be responsible for protein damage, constant vigilance is required by the chaperones $[20,40]$. This type of expression would be required to maintain cellular homeostasis in S. neumayeri at low temperatures to avoid protein damage. While thermal stress responses could be quantifiable due to increased expression of some of these genes, especially in coelomocytes, the same expression was not necessarily observed for the different tissues evaluated.

The expression found for S.neumayeri showed a different tendency to what has been determined for other marine invertebrates such as $O$. validus and $P$. gibber that lack a thermal stress response, [22]. In these invertebrates, acute temperatures of $10-15{ }^{\circ} \mathrm{C}$, for $2 \mathrm{~h}$ and then return to temperatures below zero and 2 and $6{ }^{\circ} \mathrm{C}$ for longer time periods, do not produce a significant increase in the expression of Hsp70. This latter condition, is similar to the one used by us for S. neumayeri, however, for some of the genes analyzed (Hsp90, Hyou1 and Grp78), we observed a delayed induction at $48 \mathrm{~h}$ over the control group. The expression of the Hsc70 gene in $S$. neumayeri did not vary probably because this gene is constitutive and exhibited a high identity sequence $(89 \%)$ compared to the not inducible Hsc70's from $S$. purpuratus. A recent study of two sister species of Euphausiids (Antarctic krills) Euphausia superba and Euphausia crystallorophias determined the presence of heat shock response (in terms of up-regulation of HSP70 family members), although the response is weak compared with the fold changes observed in temperate species [9]. Surprisingly some of the up-regulated Hsp70 at 3 and $6{ }^{\circ} \mathrm{C}$ have the signatures of constitutive chaperones. For this reason, we cannot exclude the presence of inducible forms of Hsp70 in S. neumayeri. Thus, it is necessary to continue with further analyses of genomic data to determine the expression of several isoforms of Hsp70.

Other HSP such as the Hsp90 are found in the cytoplasm and their primary role is cellular differentiation, protein regulation, apoptosis control and signal transduction in response to stress [41]. Studies regarding the expression of Hsp90 has been done primarily in marine 
invertebrates, demonstrating that their induction is possible against factors such as thermal stress, hypoxia, osmotic stress and presence of bacteria [42]. Little information exists about the expression of this gene in Echinoderms, where the increase of the Hsp90 expression in thermal stress has been document only in the sea cucumber Apostichopus japonicus [43, 44]. The expression of Hsp90 under thermal stress in S. neumayeri was similar in the two tissues analyzed, showing a tendency to increase its expression at $3{ }^{\circ} \mathrm{C}$ at $48 \mathrm{~h}$, but not at a higher temperature $\left(5{ }^{\circ} \mathrm{C}\right)$. This situation contrasts with that observed in the Antarctic clam Laternula elliptica where the relative expression level of Hsp90 messenger RNA at $10{ }^{\circ} \mathrm{C}$ was clearly upregulated and peaked at $12 \mathrm{~h}$ in the digestive gland and at $24 \mathrm{~h}$ in the gills, then dropped progressively [45], evidencing a faster HSP response in this mollusc compared to the sea urchin $S$. neumayeri.

Comparative physiological studies have found that other HSP such as the Grp78, it play an important role in stress mitigation, cellular protection and maintenance of the endoplasmic reticulum functions [36, 46]. For example, Grp78 can protect cells from cellular death by suppressing the accumulation of oxyradicals [47]. However, there is little information about its possible role in Antarctic organisms. The expression of Grp78 has been evaluated in gonad tissue in the Antarctic seastar $O$. validus $[20,22]$, showing that its expression is not inducible during thermal stress at different temperatures (2, 6 and $\left.10{ }^{\circ} \mathrm{C}\right)$. In contrast, the expression of Grp78 in $L$. elliptica molluscs increased in the gills, mantle and siphon $[20,48]$. In $S$. neumayeri, the overexpression of this gene has a delayed response. In L. elliptica, temperatures of 8,10 and $15{ }^{\circ} \mathrm{C}$ produce increases in Grp78 expression after $2 \mathrm{~h}$ of thermal stress. Therefore, we cannot rule out that higher temperatures could increase expression of Grp78 in S. neumayeri. The increase in temperature could also increase the quantity of reactive oxygen species because the concomitant effect on the respiratory activity in S. neumayeri (unpublished data), affecting the proteins of the endoplasmic reticulum and therefore Grp78, as well as other chaperones from the ER which could help diminish the oxidative damage $[37,49]$. In addition to the Grp78, the endoplasmic reticulum also contains the protein Hyou1 (hypoxia upregulated 1), which is in charge of the transport of mature proteins from the endoplasmic reticulum to the Golgi apparatus [50]. Under stress conditions by hypoxia, this protein accumulates in the endoplasmic reticulum. Protein suppression is associated with the increase of apoptosis, which suggests an important role in cellular perturbation caused by hypoxia [51]. The gene Hyou1 has not been studied thoroughly in marine invertebrates, however, induction under thermal stress, has been observed in the gills of the Crassostrea gigas molluscs [52]. This study is the first to document gene expression with thermal stress in Antarctic marine organisms. The increased expression in coelomocytes would indicate that these cells could resist better to damage by hypoxia and warming, at least in the shortterm.

While coelomocytes showed a greater response capacity to thermal stress associated with an increase in expression of the chaperones Hsp90, Grp78 and Hyou1, the esophagus also showed a significant tendency of increased expression for these genes. This demonstrates the necessity to broaden the number of tissues studied, as the expression of chaperones could be tissue specific and one tissue could respond more than another to a certain thermal stress condition as seen in other models $[19,48]$.

Recently studies about ocean change stressors have been developed in $S$. neumayeri. These studies have focused on the effect of a single stressor or a combination of temperature and $\mathrm{pH}$ on adult sea urchins, during fertilization and early developmental stages [53-57]. $S$. neumayeri has shown that under long term acclimation, adult stages are lest affected by two combined effect of temperature and reduced seawater $\mathrm{pH}$ [56]. In the case of fertilization and embryonic development, increased seawater temperature $\left(1.5\right.$ and $\left.3.0{ }^{\circ} \mathrm{C}\right)$ was not deleterious to fertilization at $\mathrm{pH} 7.7-8.0$ [54]. These results show that $S$. neumayeri embryos have a relatively robust response in this experimental condition may be due to the expression of heat shock proteins present in the eggs before fertilization or expressed during early developmental stages $[54,55]$. Future studies should deepen into the aspects related to the expression of different chaperone isoforms, the capacity of expression during different stages of larval development or the effect of other stress response inductors, such as hypoxia or presence of heavy metals, for example cadmium in $S$. neumayeri.

\section{Conclusions}

The sea urchin S. neumayeri showed a stress response as a result of an increased expression of three chaperones implicated in response to thermal stress. However, this response is not typical to what has been described for other Antarctic invertebrates such as the molluscs N.concinna or L. elliptica, that present a rapid increase in the HSP response. Our results, suggest that the increase in the transcription of the Hsp90, Grp78 and Hyou1 genes is associated with the repair and folding of proteins, that would assure cellular and tissue viability. The degree of expression of these chaperones in S. neumayeri suggest the existence of specific expression profiles of HSP at different levels of organismal 
organization probably as a result of differences in the thermal sensitivities and tolerances of the tissues, as well of their physical and biological compositions. Nonetheless, further investigation is necessary to elucidate the mechanisms of protection in cellular homeostasis, as well as, how the transcription levels of these genes are correlated with the expression of the proteins they encode. Finally, it is necessary to evaluate other environmental factors that could produce a response the expression of HSPs in laboratory condition and in natural populations.

\section{Competing interests}

The authors declare that they have no competing interests.

\section{Authors' contributions}

KGF and MGA conceived the study. KGF and AFM performed the majority of sequences analyses and $\mathrm{PPCR}$ data interpretation in collaboration with CAC and MGA. KGF, CAC, JDG and MGA drafted the manuscript. All authors read and approved the final manuscript.

\section{Authors' information}

KGF is a Marine Biologist and Master student at the Universidad de Magallanes (Chile). Her interests revolve around the ecological and physiological response in marine invertebrates. JGE is a Doctor in Evolution and Ecology (Universidad Austral de Chile). His interests are related to the ecophysiology of ectotherms, particularly adaptive evolution of physiological traits along environmental gradients, through the interaction of quantitative genetic and molecular approaches. AFM is an Engineer in Biotechnology (Universidad Nacional Andres Bello, Chile). His interests revolve around the molecular biology and bioinformatics issues related to cold adaptation. CAC is a PhD in Marine Biology (Victoria University of Wellington, New Zealand). Currently, he is a researcher in the Scientific Department at the Instituto Antártico Chileno. His main research is focused on benthic ecology of Antarctic and Subantarctic communities. MGA is Doctor in Parasitology (Montpellier University 2, France) specialized in molecular biology. Currently, he is a researcher in the Scientific Department at the Instituto Antártico Chileno. Actually, he is interested in the application of transcriptomic tools to try understanding how Antarctic marine invertebrates cope with warming.

\section{Acknowledgements}

This study was supported by the Fondecyt Project 1131001 and logistic support from the Chilean Antarctic Institute (INACH). We thank Jorge Holtheuer, Ignacio Garrido and María José Díaz for their support during diving activities.

\section{Author details}

'Laboratorio de Biorecursos Antárticos, Departamento Científico. Instituto Antártico Chileno, Punta Arenas, Chile. ${ }^{2}$ Instituto de Ciencias Ambientales y Evolutivas, Universidad Austral de Chile, Valdivia, Chile. ${ }^{3}$ CSIRO Oceans \& Atmosphere, GPO Box 1538, Hobart 7001TAS, Australia.

Received: 15 November 2015 Accepted: 9 February 2016

Published online: 10 March 2016

\section{References}

1. Aronson RB, Thatje S, Clarke A, Peck LS, Blake DB, Wilga CD, Seibel BA. Climate change and invisibility of the Antarctic benthos. Annu Rev Ecol Evol Syst. 2007;38:129-54

2. Clarke A, Crame JA. The Southern Ocean benthic fauna and climate change: a historical perspective. Phil Trans R Soc B Biol Sci. 1992;338:299-309.

3. DeVries AL. Biological antifreeze agents in coldwater fishes. Comp Biochem Physiol. 1982;A73:627-40

4. Morgan-Kiss RM, Priscu JC, Pocock T, Gudynaite-Savitch L, Huner NPA. Adaptation and acclimation of photosynthetic microorganisms to permanently cold environments. Microbiol Mol Biol R. 2006;70:222-52

5. Clarke A. A reappraisal of the concept of metabolic cold adaptation in polar marine invertebrates. Biol J Linnean Soc. 1980;14:77-92.
6. Marsh AG, Maxson RE, Manahan DT. High macromolecular synthesis with low metabolic cost in Antarctic sea urchin embryos. Science. 2001;291: 1950-2.

7. Ingels J, Vanreusel A, Brandt A, Catarino Al, David B, Ridder D, Dubois P, Gooday A, Martin P, Pasotti F, Robert H. Possible effects of global environmental changes on Antarctic benthos: a synthesis across five major taxa. Ecol Evol. 2012;2:453-85.

8. Peck LS, Morley SA, Richard J, Clark MS. Acclimation and thermal tolerance in Antarctic marine ectotherms. J Exp Biol. 2014;217:16-22.

9. Cascella K, Jollivet D, Papot C, Léger N, Corre E, Ravaux J, et al. Diversification, evolution and sub-functionalization of $70 \mathrm{kDa}$ heat-shock proteins in two sister species of Antarctic Krill: differences in thermal habitats, responses and implications under climate change. PLoS One. 2015; 10(4):e0121642.

10. Hofmann GE, Buckley BA, Airaksinen S, Keen J, Somero GN. Heat shock protein expression is absent in the Antarctic fish Trematomus bernacchii (Family Nototheniidae). J Exp Biol. 2000;203:2331-9.

11. Niehaus AC, Angilletta MJ, Sears MW, Franklin CE, Wilson RS. Predicting the physiological performance of ectotherms in fluctuating thermal environments. J Exp Biol. 2012;215:694-701.

12. Peck LS. Organisms and responses to environmental change. Mar Genomics. 2011:4:237-43.

13. Somero G. Proteins and temperature. Annu Rev Physiol. 1995:57:43-68.

14. Morimoto RI. Regulation of the heat shock transcriptional response: cross talk between a family of heat shock factors, molecular chaperones, and negative regulators. Genes Dev. 1998;12:3788-96.

15. Hartl FU, Hartl-Meyer M. Molecular chaperones in the cytosol: from nascent chain to folded protein. Science. 2002;295:1852-8.

16. Tomanek L. Variation in the heat shock response and its implication for predicting the effect of global climate change on species' biogeographical distribution ranges and metabolic costs. J Exp Biol. 2010;213:971-9.

17. Feder ME, Hofmann GE. Heat-shock proteins, molecular chaperones, and the stress response: evolutionary and ecological physiology. Annu Rev Physiol. 1999;61:243-82.

18. Sørensen JG, Kristensen TN. The evolutionary and ecological role of heat shock proteins. Ecol Lett. 2003:6:1025-37.

19. Clark M, Peck L. HSP70 heat shock proteins and environmental stress in Antarctic marine organisms: a mini-review. Mar Genomic. 2009;2:11-8.

20. Clark MS, Fraser K, Peck LS. Antarctic marine molluscs do have an HSP70 heat shock response. Cell Stress Chaperones. 2008;13:39-49.

21. Park H, Ahn IY, Lee HE. Expression of heat shock protein 70 in the thermally stressed antarctic clam Laternula elliptica. Cell Stress Chaperones. 2007;12: 275-82.

22. Clark MS, Fraser K, Peck LS. Lack of an HSP70 heat shock response in two Antarctic marine invertebrates. Polar Biol. 2008:31:1059-65.

23. Shin SC, Ahn DH, Kim SJ, Pyo CW, Lee H, Kim MK, Lee J, Lee JE, Detrich HW, Postlethwait JH, Edwards D, Lee SG, Lee JH, Park H. The genome sequence of the Antarctic bullhead notothen reveals evolutionary adaptations to a cold environment. Genome Biol. 2014;15:468.

24. Somero GN. The physiology of climate change: how potentials for acclimatization and genetic adaptation will determine 'winners' and 'losers'. J Exp Biol. 2010;213:912-20.

25. Meredith MP, King JC. Rapid climate change in the ocean west of the Antarctic Peninsula during the second half of the 20th century. Geophys Lett. 2005;32:L19604-9.

26. Turner JA, Barrand NE, Bracegirdle TJ, et al. Antarctic climate change and the environment: an update. Polar Rec. 2014;254:237-59.

27. Schram JB, McClintock JB, Amsler CD, Baker BJ. Impacts of acute elevated seawater temperature on the feeding preferences of an Antarctic amphipod toward chemically deterrent macroalgae. Mar Biol. 2015;162:425-33.

28. Peck LS, Webb KE, Bailey DM. Extreme sensitivity of biological function to temperature in Antarctic marine species. Funct Ecol. 2004;18:625-30.

29. Peck LS, Morley SA, Clark MS. Poor acclimation capacities in Antarctic marine ectotherms. Mar Biol. 2010;157:2051-9.

30. Peck LS. Ecophysiology of Antarctic marine ectotherms: limits to life. Polar Biol. 2002;25:31-40.

31. Peck LS, Webb KE, Clark MS, Miller A, Hill T. Temperature limits to activity, feeding and metabolism in the Antarctic starfish Odontaster validus. Mar Ecol Prog Ser. 2008;381:181-9.

32. IPCC. Summary for Policymakers. In: Stocker TF, Qin D, Plattner G-K, Tignor M, Allen SK, Boschung J, Nauels A, Xia Y, Bex V, Midgley PM, editors. Climate 
Change 2013: The Physical Science Basis. Contribution of Working Group I to the Fifth Assessment Report of the Intergovernmental Panel on Climate Change. Cambridge, New York: Cambridge University Press; 2013.

33. Dilly GF, Gaitán-Espitia JD, Hofmann GE. Characterization of the Antarctic sea urchin (Sterechinus neumayeri) transcriptome and mitogenome: a molecular resource for phylogenetics, ecophysiology and global change biology. Mol Ecol Resour. 2015;15:425-36.

34. Chen B, Zhong D, Monteiro A. Comparative genomics and evolution of the HSP90 family of genes across all kingdoms of organisms. BMC Genomics. 2006;:156.

35. Mayer MP, Bukau B. Hsp70 chaperones: Cellular functions and molecular mechanism. Cell. Mol Life Sci. 2005;62:670-84.

36. Kaufman RJ. Stress signaling from the lumen of the endoplasmatic reticulum: coordination of gene transcriptional and translational controls. Genes Dev. 1999:13:1211-33.

37. Shen X, Zhang K, Kaufman RJ. The unfolded protein response a stress signaling pathway of the endoplasmatic reticulum. J Chem Neuroanat. 2004;28:79-92.

38. Livak K, Schmittgen T. Analysis of relative gene expression data using real time quantitative PCR and the $2 \mathrm{dd}$ ct method. Methods. 2001;25:402-8.

39. Constable A, Melbourne-Thomas J, Corney SP, Arrigo KR, Barbraud C, Barnes DKA, et al. Climate change and Southern Ocean ecosystems I: how changes in physical habitats directly affect marine biota. Glob Chang Biol. 2014;20: 3004-25.

40. Place SP, Hofmann GE. Comparison of Hsc70 orthologs from polar and temperate notothenioid fishes: differences in prevention of aggregation and refolding of denatured proteins. Am J Physiol Regul Integr Comp Physiol. 2005;288:R1195-202.

41. Wu LT, Chu KH. Characterization of heat shock protein $90 \mathrm{in}$ the shrimp Metapenaeus ensis: Evidence for its role in the regulation of vitellogenin synthesis. Mol Reprod Dev. 2008;75:952-9.

42. Fu D, Chen J, Zhang Y, Yu Z. Cloning and expression of a heat shock protein (HSP) 90 gene in the haemocytes of Crassostrea hongkongensis under osmotic stress and bacterial challenge. Fish Shellfish Immunol. 2011; 31:118-25.

43. Xu D, Sun L, Liu S, Zhang L, Yang H. Polymorphisms of heat shock protein 90 (Hsp90) in the sea cucumber Apostichopus japonicus and their association with heat- resistance. Fish Shellfish Immunol. 2014:41:428-36.

44. Zhao $\mathrm{H}$, Yang $\mathrm{H}$, Zhao $\mathrm{H}$, et al. The molecular characterization and expression of heat shock protein 90 (Hsp90) and 26 (Hsp26) CDNAs in sea cucumber (Apostichopus japonicus). Cell Stress Chaperones. 2011;16:481-93.

45. Kim M, Ahn IY, Kim H, Cheon J, Park H. Molecular characterization and induction of heat shock protein 90 in the Antarctic bivalve Laternula elliptica. Cell Stress Chaperones. 2009;14:363-70.

46. Sherman MY, Goldberg AL. Cellular defenses against unfolded proteins: a cell biologist thinks about neurodegenerative diseases. Neuron. 2001;29:1532.

47. Yu Z, Luo H, Fu W, Mattson MP. The endoplasmic reticulum stressresponsive protein GRP78 protects neurons against excitotoxicity and apoptosis: suppression of oxidative stress and stabilization of calcium homeostasis. Exp Neurol. 1999;155:302-14.

48. Clark MS, Thorne MAS, Burns G, Peck LS. Age-related thermal response: the cellular resilience of juveniles. Cell Stress Chaperones. 2016;21:75-85.

49. Hayashi T, Saito A, Okuno S, Ferrand-Drake M, Dodd RL, Nishi T, Maier CM, Kinouchi $\mathrm{H}$, Chan PH. Oxidative damage to the endoplasmic reticulum is implicated in ischemic neuronal cell death. Cereb Blood Flood Metab. 2003; 23:1117-28.

50. Bando Y, Ogawa S, Yamauchi A, Kuwabara K, Ozawa K, Hori O, Yanagi H, Tamatani M, Tohyama M. 150-kDa oxygen-regulated protein (ORP150) functions as a novel molecular chaperone in MDCK cells. Am J Physiol Cell Physiol. 2000;278:C1172-82.

51. Krętowski R, Stypułkowska A, Cechowska-Pasko M. Low-glucose medium induces ORP150 expression and exerts inhibitory effect on apoptosis and senescence of human breast MCF7 cells. Acta Biochim Pol. 2013;60:167-73.

52. Meistertzheim AL, Tanguy A, Moraga D, Thébault MT. Identification of differentially expressed genes of the Pacific oyster Crassostrea gigas exposed to prolonged thermal stress. Fed Eur Biochem Soc. 2007;274:6392-402.

53. Byrne $M, H o M A$, Koleits $L$, et al. Vulnerability of the calcifying larval stage of the Antarctic sea urchin Sterechinus neumayeri to near-future ocean acidification and warming. Glob Chang Biol. 2013;19:2264-75.
54. Ericson JA, Ho MA, Miskelly A, King CK, Virtue P, Tilbrook B, Byrne M. Combined effects of two ocean change stressors, warming and acidification, on fertilization and early development of the Antarctic echinoid Sterechinus neumayeri. Polar Biol. 2012;35:1027-34.

55. Kapsenberg L, Hofmann GE. Signals of resilience to ocean change: high thermal toleranceof early stage Antarctic sea urchins (Sterechinus neumayeri) reared under present-day and future $\mathrm{pCO} 2$ and temperature. Polar Biol. 2014;37:967-80.

56. Suckling CC, Clark MS, Richard J, Morley SA, Thorne MAS, Harper EM, Peck LS. Adult acclimation to combined temperature and $\mathrm{pH}$ stressors significantly enhances reproductive outcomes compared to short-term exposures. J Anim Ecol. 2015;84:773-84

57. Yu PC, Sewell MA, Matson PG, Rivest EB, Kapsenberg L, Hofmann GE. Growth attenuation with developmental schedule progression in embryos and early larvae of Sterechinus neumayeri raised under elevated CO2. PLoS One. 2013;8:e52448

\section{Submit your next manuscript to BioMed Central and we will help you at every step:}

- We accept pre-submission inquiries

- Our selector tool helps you to find the most relevant journal

- We provide round the clock customer support

- Convenient online submission

- Thorough peer review

- Inclusion in PubMed and all major indexing services

- Maximum visibility for your research

Submit your manuscript at www.biomedcentral.com/submit 